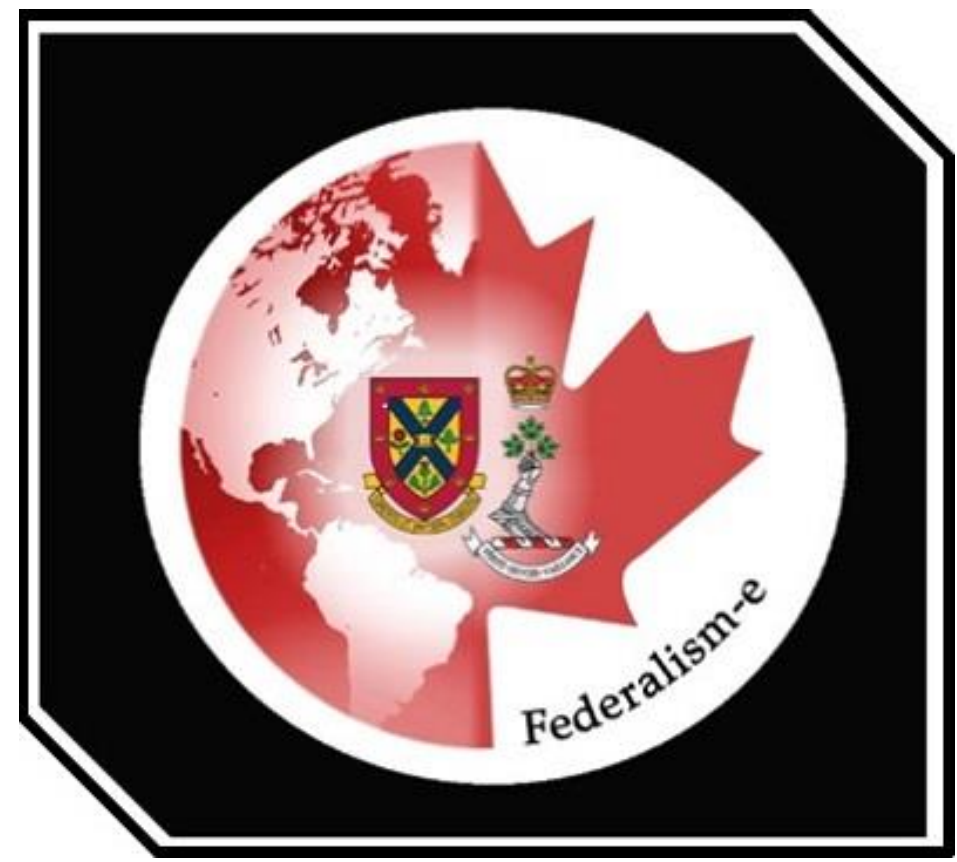

\title{
The Democratic Federalist
} System

William Ye

Queen's University

Federalism-E is founded by the Royal Military College of Canada and the Institute of Intergovernmental Relations at Queen's University - ISSN 2562-3435 
Federalism-e is an electronic student journal about federalism, multi-level governance, and intergovernmental relations put forth in collaboration between Queen's University and the Royal Military College of Canada. This annual journal will publish papers by undergraduate students, which are reviewed by an editorial board composed of their peers, in both English and French languages. It is a bilingual, undergraduate electronic journal with a mandate to provide a forum to encourage research and scholarly debate with respect to a wide variety of issues concerning federalism both within Canada and abroad.

Federalism-e est un journal électronique sur le fédéralisme, la gouvernance à plusieurs niveaux et les relations intergouvernementales, élaboré en collaboration avec I'Université Queen's et le Collège militaire royal du Canada. Ce journal annuel publiera des articles d'étudiants de premier cycle, qui seront examinés par un comité de rédaction composé de leurs pairs, en anglais et en français. II s'agit d'un journal bilingue de premier cycle dont le mandat est de fournir un forum pour encourager la recherche et les débats universitaires sur une grande variété de questions relatives au fédéralisme au Canada et à l'étranger.

\section{Editors-in-Chief/redacteurs en chef:}

Officer Cadet/élève-officier Daniel Walcott, Royal Military College of Canada

Naval Cadet/aspirant de marine Jack Murphy, Royal Military College of Canada

\section{Associate Editors/rédacteurs associés:}

Officer Cadet/élève-officier Damien McCracken, Royal Military College of Canada Charmaine Lee, University of British Columbia

Jenna Mohammad, University of Toronto

Srjan Sahu, University of Toronto

Mduduzi Mhlanga, University of Toronto

Reeba Khan, University of Toronto

Joyce Le-Yi Yang, University of Toronto

Hollis MacKenzie, University of British Columbia

\section{Faculty Advisor/conseiller de la faculté:}

Dr. Christian Leuprecht, Royal Military College of Canada, Institute of Intergovernmental Relations at Queen's University

\section{Contact Information:}

Email/courriel - federalismeditors@gmail.com

Website/site web - https://ojs.library.queensu.ca/index.php/fede

Address/adresse - Royal Military College of Canada

13 General Crerar Cres

Kingston, ON

K7K 7B4

Federalism-E is founded by the Royal Military College of Canada and the Institute of Intergovernmental Relations at Queen's University - ISSN 2562-3435 
Federalism and democracy go hand in hand. As will be demonstrated and defined in this paper, federalism enhances the principles of democracy by creating accountable governments, increasing political participation, and protects against the tyranny of the majority. Federalism as a system is defined as two or more authorities in a given area but are unified under a singular government. This is usually done by producing a regional government and a national/federal government. ${ }^{1}$ The definition of democracy can vary depending on who is asked but according to Ralf Dahrendorf, democracy aims to legitimize the exercise of political power by answering 3 questions: "How can we achieve change in our society without violence"; "How can we, through a system of checks and balances, control those who are in power in a way that gives us assurance that they will not abuse it?"; "How can the people - all the citizens - have a voice in the exercise of power?". 2 Democracy, therefore, should allow for: change in society without violence, regulate those in power, and adhere to the will of the people. To enhance democracy, then, is to ensure government is transparent, accountable and within its boundaries. Furthermore, enhancement of democracy should promote citizen political participation, and to ensure the people's will is being heard and obeyed. This paper will argue that federalism in Canada accomplishes the aforementioned traits and therefore enhances democracy. As a system, federations have higher levels of political participation and less state corruption as citizens are closer to their governments. This forces sub-states to be more transparent and accountable, while citizens feel more influential and become more politically involved. ${ }^{3}$ Federalism, by nature, protects minority groups in multinational states by giving these groups an area to govern and to have their voice heard. This is clear within Quebec, where the federal government gives the province special powers to protect their distinct culture. The tiered system of federalism forces competition between sub-states to ensure a standard of protection when it comes to rights and civil liberties. If sub-states fail, however, the central government can play as an insurance policy to prevent further infringement. Federalism, through reducing corruption and increasing political participation, protecting minority groups and their interest, and ensuring a standard of protection when it comes to rights and civil liberties, enhances democratic principles, as previously defined.

Federations tend to have greater political participation, as demonstrated by higher voter turnout rates and greater numbers of party memberships. Citizens within smaller districts are more likely to keep up to date with local issues rather than national ones due to the proximity of the issue being right at the front door. Politicians and their activities are more accessible the

${ }^{1}$ Jenna Bednar, "The Political Science of Federalism," Annual Review of Law and Social Science 7, no. 1 (2011) 271, https://doi.org/10.1146/annurev-lawsocsci-102510-105522.

2 Ralf Dahrendorf, "A Definition of Democracy," Journal of Democracy 14, no. 4 (2003) 327-328, https://doi.org/10.1353/jod.2003.0068; R. P. Inman, "Federalism's values and the value of federalism," Cesifo Economic Studies 53, no. 4 (Dec 2007); Daniel L. Rubinfeld and Robert P. Inman, "Federalism," En (2000). 
smaller the district becomes and as a result, citizens know their options better. ${ }^{4}$ A study done on Sweden showed that citizens in smaller districts were more aware of local politics when compared to citizens of larger. ${ }^{5}$ Citizens feel more influential within smaller districts and thus they are more likely to be politically active. The same study also showed, through comparing data from the United States, the Netherlands (as a decentralized unitary state for comparison) and Switzerland that smaller districts (in the United States through states, and in Switzerland through cantons) usually voice their opinion through votes, whereas larger districts are more likely to be voiced through political parties or interest groups. This study also showed, within the United States, the feeling of political powerlessness and the size of sub-states are positively correlated. ${ }^{6}$ What this study demonstrates is that citizens of smaller districts feel like they have more influence as an individual rather than feeling the need to partake in interest groups in order to have a voice. Votes are also a formal, more direct, method of democracy whereas interest groups are less direct and many times informal. What this fundamentally demonstrates is that smaller voting districts promote citizens' trust in government. By voting, it shows an inherent belief in the ability of government to adhere and listen to citizens because they are acting within the system. In contrast, interests groups are an externality and show a (relatively) lack of trust in government adherence. Therefore, it can be further extended that smaller communities seem to have a greater trust within government and democracy itself. Overall, federations tend to produce districts that are more politically active and trust their government, enhancing the overall democratic experience by engaging and legitimizing the citizens and state.

Federations tend to be less corrupt as politicians are under a closer scope because they are closer to the citizens and their actions are more easily accessible. As sub-states tend to specialize in tasks, politicians tend to be more accountable for their actions than their unitary counterparts. Unitary politicians' performance can be linked to many different tasks as the central government takes care of them. The result is aggregate performance versus federalism's singular performance. Politicians in federations are directly linked to a singular performance, providing incentive to be less corrupt as corruption can impair economic performance and hinder chances for re-election or higher office. ${ }^{7}$ On the other hand, politicians in unitary systems have every incentive to be corrupt as their performance is aggerated rather than singular. Fiscal decentralization reduces the ability of politicians to extract bribes from firms or individuals. In order for governments or politicians to extract bribes, the use of heavy regulation in industry are necessary to extract bribes. Without regulation, firms do not see incentives to pay bribes. However, firms that see heavy regulation in one sub-state may simply move to another to escape

\footnotetext{
${ }^{4}$ Inman, "Federalism's values and the value of federalism."

${ }^{5}$ Rubinfeld and Inman, "Federalism."

${ }^{6}$ Ibid.
}

${ }^{7}$ Fisman and Gatti, "Decentralization and corruption: evidence across countries," 327328. 
such regulations and thus the sub-state receives less taxation due to less economic activity in the area. It is important to note that if all sub-states are corrupt, this becomes terrible for firms as they cannot escape regulation and must resort to bribes in order to stay competitive (relative to other firms). ${ }^{8}$ Another study demonstrated that the greater number of tiers a federation has, the more likely bribes and corruption are to take place because greater number of tiers lead to greater specialization, which can lessen competition if specialized enough. However, the study did conclude that greater fiscal decentralization along with a greater capacity to raise funds reserved and reduced these effects of corruption. ${ }^{9}$ Reducing government corruption creates transparency and thus would result in greater confidence in the government.

Federalism allows for greater political participation with decreased corruption. The ability for sub-states to raise their own funds is heavily tied with reduced corruption. All these traits aid in the democratic process and experience. Increased political participation and voter turnout allow the citizen's voice to be heard and legitimizes elected office. Politicians in federations have incentive to not be corrupt and to boost the performance of their constituency. This, in turn, creates a positive feedback loop that increases political participation and reduces corruption, overall, creating a better relationship between citizen and state. Federalism, therefore, enhances democracy and aids in representation.

Democracy, as a system, acts on the will of the people. As mentioned by Schmitter and Karl (1991), democracy's primary limitation is that minorities can suffer due to the tyranny of the majority. Schmitter and Karl talk about “... constitutional provisions that place certain matters beyond the reach of majorities...". ${ }^{10}$ Federalism aims to fix this. Under federalism, minority populations can govern themselves without the majority will being imposed on them effectively creating national minorities into local majorities. This is especially useful when the state is multinational. Legislators tend to only consider the majority as appealing to the majority results in elections. Minorities, as a result, tend to get the short end of the stick. Federalism, by nature, allows local minorities to have a voice. Unitary systems, on the other hand, may pay little or no attention to minorities and the result is the oppression of a group. Take Scotland within the UK and Quebec in Canada. The difference is, the UK is a unitary system whereas Canada is a federal system. Key events demonstrate how minority nations are treated within the federalist model and the unitary model.

${ }^{8}$ Fisman and Gatti, "Decentralization and corruption: evidence across countries," 330.

${ }^{9}$ C. Simon Fan, Chen Lin, and Daniel Treisman, "Political decentralization and corruption: Evidence from around the world," Journal of Public Economics 93, no. 1-2 (2009) 19, https://doi.org/10.1016/j.jpubeco.2008.09.001.

${ }^{10}$ Philippe C. Schmitter and Terry Lynn Karl, "What Democracy Is. . . and Is Not," Journal of Democracy 2, no. 3 (1991)79, https://doi.org/10.1353/jod.1991.0033. 
As Brexit takes place, the will of the Scottish people remain ignored. As a unitary state, the UK government can effectively ignore a whole nation so long as a majority is in place. Informal methods of devolution were in place for Scotland which allowed them to govern many actions themselves, however, as it was never constitutionally entrenched, Scotland has no other choice but to accept Brexit or declare independence. ${ }^{11}$ Data comparing the Brexit votes between Scotland, Northern Ireland, Wales and England show that Scotland overwhelmingly voted to remain. ${ }^{12}$ Scotland and England traditionally have had a history of taking different stances on issues. Issues such as support for the welfare state, taxation, or the fundamental role of the state in everyday life show diverging political stances between Scotland and England. ${ }^{13}$ England has 10 times the population that Scotland does $(55,977,000$ versus 5,438,000) and in the unitary system, this gives England a drastic advantage when it comes to national policies such as Brexit. ${ }^{14}$ It makes no sense that a state with multiple distinct policy preferences does not engage in further devolution. And while Scottish parliament does exist and has the capacity of enact laws in certain jurisdictions, such as education, environment, or certain taxes, its power are at the complete whim of Westminster. These powers are given and can be taken away by acts of Parliament. ${ }^{15}$ And as stated before, if England holds a majority population and has differing preferences to Scotland, such devolution can be done away without any meaningful input. It is no surprise Scotland has held 2 independence referenda and in the wake of Brexit, wants to hold another. The suppression of a whole minority nation that can occur within unitary systems hinders the very idea of democracy. Federalism becomes useful in situations like this because national minorities, that otherwise would be a local majority, hold differing preferences.

This is where federalism shines by enhancing the principles of democracy and representation. Quebec is an excellent example of federalism protecting against the tyranny of the majority by providing special powers to self-govern, to an extent. Immigration and settlement, for example, is an area in which Quebec received and kept special privileges before

${ }^{11}$ Aileen McHarg and James Mitchell, "Brexit and Scotland," The British Journal of Politics and International Relations 19, no. 3 (2017) 514, https://doi.org/10.1177/1369148117711674.

12 Ibid., 513.

${ }^{13}$ M. K. Thompson, "Brexit, Scotland, and the Continuing Divergence of Politics," Midwest Quarterly-a Journal of Contemporary Thought 60, no. 2 (Win 2019), 147-149.

${ }^{14}$ Office for National Statistics "Population Estimate" UK Government” June 26, 2019, https://www.ons.gov.uk/peoplepopulationandcommunity/populationandmigration/populationesti mates, 9.

${ }^{15}$ McHarg and Mitchell, "Brexit and Scotland," 515. 
and after every other province. ${ }^{16}$ Section 95 of the Constitutional Act states that immigration is a shared jurisdiction, however, any act of parliament will supersede provincial law. ${ }^{17}$ This effectively allows the federal government to take charge and set any and all standards it wants. The federal government has exercised this power on every province with the exception of Quebec. A series of agreements starting from 1971's Lang-Cloutier agreement to the 1991 Canada-Quebec accord demonstrated asymmetric federalism to protect Quebec's distinct culture. Quebec has its own set of standards when it comes to immigration that differ from the federal government's and was also given the option to opt-out of federal integration services in favour of a grant, an option other provinces did not receive until 2009. ${ }^{18}$ Other provinces were eventually given an option to control immigration to a greater extent through the Provincial Nominee Program (PNP) and also given the option to opt-out of federal integration services in favour of a grant. This decentralization of immigration would be short-winded as the federal government recentralized the PNP and took away the option of a grant for every province except for Quebec. ${ }^{19}$ If immigration was completely centrally controlled, Quebec's population would slowly be assimilated into English Canada's culture, with many immigrants who may not adopt Quebec's culture. This would effectively destroy the French-Canadian nation. Quebec, understanding the risks associated with immigration, was very selective. ${ }^{20}$ The asymmetric powers that Quebec holds allows for special protection of the French-Canadian culture in a predominately English country.

Through protecting a minority in a majority nation, by giving special governing powers, the will of a minority can still be heard and executed. As seen in the UK, the unitary system undermines the Scottish voice whereas, in Canada, the federalist system listens to the FrenchCanadian voice. The fact that a nation can overwhelmingly agree against a decision but still have that decision enacted upon them is the complete opposite of what democracy entails. If democracy is where people's voices are heard and obeyed, it is best executed through federalism.

${ }^{16}$ Guy LaForest, "What Canadian Federalism Means in Quebec," Review of Constitutional Studies 15, no. 1 (2010); Davide Strazzari, "Immigration and Federalism in Canada: beyond Quebec Exceptionalism?" Perspectives on Federalism 9, no. 3 (2017), https://doi.org/10.1515/pof-2017-0020.

${ }^{17}$ Distribution of Legislative Powers, s. 95, Part VI Constitution Act of 1867 https://lawslois.justice.gc.ca/eng/const/page-4.html.

${ }^{18}$ Strazzari, "Immigration and Federalism in Canada: beyond Quebec Exceptionalism?" 71.

${ }^{19}$ Ibid.

${ }^{20}$ Chris Kostov, "Canada-Quebec Immigration Agreements (1971-1991) and Their Impact on Federalism," American Review of Canadian Studies 38, no. 1 (2009), 93 https://doi.org/10.1080/02722010809481822. 
Protection of rights and civil liberties is essential in any democracy as, without such protections, any government would be able to step over its citizens. Unitary systems have the ability to protect rights to a great degree as their jurisdiction and their ability to exercise power in those jurisdictions are larger and stronger due to centralized resources. This being said, if a tyrannical government took over, tyrants have great jurisdiction and ability to exercise power. Essentially, one is hoping for the goodwill of the government. Federalist systems carry a unique form of protection in the form of competition and the insurance policy of the central government is the sub-state fails. Tiebout (1956) ${ }^{21}$ proposes the idea that sub-states will compete for citizens as how firms compete for consumers. The theory of the mobile citizen, like the theory of the firm, carries that innovations to policy and law should occur efficiently as sub-states compete with each other for citizens. The theory also holds that citizens will move to a competitor substate if services are inadequate there or rights are being infringed upon. ${ }^{22}$ Though federalist systems do not have the same jurisdictional power and resources as unitary systems, the competition of federalist systems forces high standards for the protection of rights and civil liberties. Through the threat of competition taking away potential taxpayers, governments must act efficiently, promptly, and act in a manner in which the people are appeased. Alberta's tax rate is a prime example of competition among provincial governments. Alberta, British Columbia and to some extent, Ontario, seem to compete with each other for competitive tax rates and advantages to attract business. ${ }^{23}$

The protection of rights and civil liberties will be held to a high standard expect in the case of infringement of a minority group within local government, such as the case in the United States in the 1960s regarding civil liberties issues and the later passing of the Civil Rights Act. By using Tiebout's $(1957)^{24}$ theory of the mobile citizen, one can deduce that no sub-state competed over African Americans at the time. The standard of protection that otherwise would exist did not protect civil liberties. Instead of protecting the civil liberties of African Americans, local governments attempted to suppress them through bureaucratic means such as refusals of permits. Local governments lacked the resources to provide solutions and districts dominated fiercely by segregation faced significant resistance by the white community when local solutions

${ }^{21}$ C. M. Tiebout, "A Pure Theory of Local Expenditures," Journal of Political Economy 64, no. 5 (1956), 418-419, https://doi.org/Doi 10.1086/257839.

${ }^{22}$ Ibid.

${ }^{23}$ Ben Eisen, Steve Lafleur, and Miliagros Palacios, "The End of the Alberta Tax Advantage," The Fraser Institute (2007), 11-20.

24 Tiebout, "A Pure Theory of Local Expenditures," 418-419. 
were even proposed. ${ }^{25}$ As violence ensued and the local governments' refusal to do anything, the federal government's hand was forced and The National Guard was sent. In 1963, Kennedy proposed the Civil Rights Act. The central government can act as an insurance policy when substates fail as it did in the Civil Rights Movement. As failures of sub-states threaten the stability and unity of the nation as a whole, the central government has the incentive to aid sub-states when they fail. Federalism theoretically and practically tackles the problem of the protection of rights better than the unitary model. Theoretically, its competition provides an incentive to perform better and protect rights and civil liberties. In a practical sense, if many localities have the same problem, the central government can act to solve these problems. This two-tier system allows for an insurance policy when it comes to the protection of rights and civil liberties.

Federalism provides effective measures to enhance the principles of liberal democracy and representation. Citizens within local districts have a better relationship with the local government and consistently show greater levels of political participation. Furthermore, local governments have the incentive to reduce corruption as, in federations, politician's performance can be linked to economic performance. As corruption is economically inefficient, politicians seeking re-election or higher office will have the incentive to reduce corruption. Protection of minorities within majority nations, such as Quebec in Canada, are better in federalist states versus their unitary counterparts, such as Scotland in the UK. The ability to locally govern allows the wishes of minorities to still be respected and allows for the protection of culture within a multinational state. As seen with the special powers given to Quebec, federalism protects the French-Canadian culture, while as seen with Brexit, unitary systems can ignore the will of a whole nation, so long as a majority elsewhere exist. Protection of rights and civil liberties, an essential principle of democracy, is better adhered in federalist systems. Sub-states have great incentives to compete for mobile citizens, therefore adhering to a standard of services and protections. When all sub-states fail, however, the central government can step in as an insurance policy. As demonstrated in the Civil Rights Movement, this multi-tiered system allows constant insurance that rights and civil liberties will be protected. As the world becomes more globalized and regional differences appear clearer cut, questions of how to govern democratically, while respecting the wishes of everyone are asked more. The answer is clear: federalism provides effective measures to enhance the principles of democracy and representation.

${ }^{25}$ Kenneth T. Andrews and Sarah Gaby, "Local Protest and Federal Policy: The Impact of the Civil Rights Movement on the 1964 Civil Rights Act," Sociological Forum 30 (2015), 510-511, https://doi.org/10.1111/socf.12175. 


\section{Bibliography}

Andrews, Kenneth T., and Sarah Gaby. "Local Protest and Federal Policy: The Impact of the Civil Rights Movement on the 1964 Civil Rights Act." Sociological Forum 30 (2015): 509-27. https://doi.org/10.1111/socf.12175.

Bednar, Jenna. "The Political Science of Federalism." Annual Review of Law and Social Science 7, no. 1 (2011): 269-88. https://doi.org/10.1146/annurev-lawsocsci-102510-105522.

Dahrendorf, Ralf. "A Definition of Democracy." Journal of Democracy 14, no. 4 (2003): 103-03. https://doi.org/10.1353/jod.2003.0068.

Canada. Distribution of Legislative Powers, s. 95, Part VI Constitution Act of 1867 https://laws-lois.justice.gc.ca/eng/const/page-4.html

Eisen, Ben, Steve Lafleur, and Miliagros Palacios. "The End of the Alberta Tax Advantage." The Fraser Institute (2007): 1-43.

Fan, C. Simon, Chen Lin, and Daniel Treisman. "Political Decentralization and Corruption: Evidence from around the World." Journal of Public Economics 93, no. 1-2 (2009): 1434. https://doi.org/10.1016/j.jpubeco.2008.09.001.

Fisman, R., and R. Gatti. "Decentralization and Corruption: Evidence across Countries." [In English]. Journal of Public Economics 83, no. 3 (Mar 2002): 325-45. https://doi.org/Pii S0047-2727(00)00158-4

Inman, R. P. "Federalism's Values and the Value of Federalism." [In English]. Cesifo Economic Studies 53, no. 4 (Dec 2007): 522-60. <Go to ISI>://WOS:000254076200003.

Kostov, Chris. "Canada-Quebec Immigration Agreements (1971-1991) and Their Impact on Federalism." American Review of Canadian Studies 38, no. 1 (2009): 91-103. https://doi.org/10.1080/02722010809481822.

LaForest, Guy. "What Canadian Federalism Means in Quebec." Review of Constitutional Studies 15, no. 1 (2010): 33.

McHarg, Aileen, and James Mitchell. "Brexit and Scotland." The British Journal of Politics and International Relations 19, no. 3 (2017): 512-26. https://doi.org/10.1177/1369148117711674.

Rubinfeld, Daniel L., and Robert P. Inman. "Federalism." En (2000): 31. 
Schmitter, Philippe C., and Terry Lynn Karl. "What Democracy Is...And Is Not." Journal of Democracy 2, no. 3 (1991): 75-88. https://doi.org/10.1353/jod.1991.0033.

Strazzari, Davide. "Immigration and Federalism in Canada: Beyond Quebec Exceptionalism?". Perspectives on Federalism 9, no. 3 (2017): E-56-E-84. https://doi.org/10.1515/pof-20170020.

Thompson, M. K. "Brexit, Scotland, and the Continuing Divergence of Politics." [In English]. Midwest Quarterly-a Journal of Contemporary Thought 60, no. 2 (Win 2019): 141-59.

Tiebout, C. M. "A Pure Theory of Local Expenditures." [In English]. Journal of Political Economy 64, no. 5 (1956): 416-24. https://doi.org/Doi 10.1086/257839.

UK. Office for National Statistics "Population Estimate" UK Government” June 26, 2019, https://www.ons.gov.uk/peoplepopulationandcommunity/populationandmigration/populat ionestimates. 